\title{
História e Ação Política em MaQuiavel
}

\author{
José Luiz Ames ${ }^{1}$
}

\section{A}

vida histórica aparece em Maquiavel marcada por um conjunto de nuanças dentre as quais a mais relevante, talvez, seja a convicção de sua radical imanência em oposição à transcendência medieval. 0 movimento histórico adquire sentido nele mesmo, e não pela realização de desígnios extraterrenos. Para 0 historiador de Florença, o homem se realiza na terra e, conseqüentemente, os fins que persegue devem também ser terrenos. Assim é que a análise da concepção maquiaveliana de história implica no estudo de algumas questões fundamentais: a finalidade do conhecimento histórico; o sentido da imitação dos antigos; o problema da mutação histórica; as causas da decadência dos Estados. Este artigo tem em vista elucidar estas questões.

\section{A Finalidade do Conhecimento Histórico}

Maquiavel era obcecado por uma idéia: estabelecer regras gerais da ação política. Para a realização deste objetivo, ele desvinculou o âmbito do agir político das determinações formais da moral tradicional, não subordinando mais a política a estes pressupostos, nem aos da religião. A formação do dirigente político deveria seguir um programa de capacitação, por meio do conhecimento histórico. Para tanto, era preciso investigar o destino real das ações. Isto significa que Maquiavel precisava desenvolver uma 'praxeologia' capaz de explicitar os fatores fundamentais que determinavam o campo político. Somente dessa maneira seria possível obter uma descrição do âmbito a partir do qual o agente político alcançaria êxito. Esta preparação supõe uma rede conceitual por intermédio da qual Maquiavel procura captar o material da experiência histórica antiga e moderna, segundo o critério de sua utilidade prática.

Doutor em Filosofia pela Unicamp. Professor do Depto. de Filosofia da Universidade Estadual do Oeste do Paraná. É autor do livro Maquiavel: a lógica da ação política. Editora da Unioeste. 
Para formular as regras da ação política, Maquiavel promete, na parte introdutória dos Discorsi, seguir "um caminho ainda não trilhado por ninguém" (Discorsi I, Introdução) ${ }^{2}$ Isso requer que a história seja considerada obra humana, como um encadeamento de ações e de seus resultados capazes de serem esclarecidos causalmente. Somente assim é possível extrair " toda utilidade pela qual se deve buscar o conhecimento da história" (Discorsi I, Introdução). A consideração pragmática da história opõe-se à compreensão cristã-medieval. Com efeito, não é possível aprender nada partindo de uma concepção teleológica, ou de uma soteriologia do pecado e do juízo. É impossível uma consideração pragmática da história quando ela é concebida como efeito da ação salvífica divina, de um lado, e do pecado humano, de outro. A concepção teológica do cristianismo medieval renunciou à noção de Historia magistra vitae, válida para o mundo antigo. Seu finalismo providencialista opôs-se a esses pressupostos teórico-cognoscitivos. Deslocando o acontecimento histórico para o campo das categorias normativo-morais, transforma-o num sinal da pecaminosidade humana e, conseqüentemente, sujeita-o ao castigo divino. Para Maquiavel, se as ações humanas representassem de alguma maneira uma expressão terrena da ira divina acerca da ruína moral do povo, então não seria possível extrair disso nenhum conhecimento válido. Para que a história se constituisse em mestra do agir político, seria preciso que os homens estivessem situados muito concretamente em sua dimensão terrena, condição na qual se encontrariam apenas quando apreendidos no espaço e no tempo e, portanto, não subordinados a finalidades exteriores à própria ação humana.

A perspectiva imanentista da história precisa criar sentido unicamente dos próprios acontecimentos considerados em sua singularidade. Isso, porém, não impediu Maquiavel de adotar Roma antiga como exemplo histórico modelar. Na história de Roma, mais do que em qualquer outro povo, seria possível, segundo ele, ler a história universal. Roma possuía a virtude de revelar a dimensão histórica das sociedades de uma forma melhor do que todos os demais povos da Antigüidade. Em vez de se fechar numa forma determinada de governo, Roma foi marcada pelo conflito que, pelas turbulências provocadas, colocava permanentemente em jogo a estabilidade do Estado.

Contudo, é preciso ter claro que uma coisa é aprender a decifrar a linguagem universal da política a partir da história romana; outra coisa é querer colocar esta linguagem em uso numa sociedade. Para Maquiavel, não interessava o conhecimento

Michinvel.ı, Nıccolò. Discorsi sopra la prima deca di Tito Livio. In Tutte le Opere. Firenze, Sansoni, 1992, p. 73254. Citaremos esta obra pela primeira palavra de seu título original seguido de um número em romano que indica o livro e outro em arábico que corresponde ao capítulo. 
histórico como um saber desinteressado dos fatos. Ele se ocupava da história para decifrar nos acontecimentos passados meios de ação eficazes para a condução do Estado em seu tempo presente. Maquiavel tinha clareza que "não se conhece toda a verdade sobre as coisas antigas, porque na maior parte das vezes se ocultam as infâmias e se magnificam e amplificam as glórias" (Discorsi II, Introdução). Além disso, "a maioria dos escritores são tão obedientes à fortuna dos vencedores que, para fazer mais gloriosas suas vitórias, não somente aumentam suas valorosas ações, como ilustram de tal modo os atos do inimigo que todos aqueles que nascem depois em qualquer dos dois países, ou do vencedor ou do vencido, têm motivos para maravilhar-se daqueles homens e daqueles tempos e são forçados a louvá-los e amá-los em grau máximo". (Discorsi II, Introdução).

Écerto que tais atitudes comprometeriam a veracidade histórica dos relatos. Isto, porém, não inviabilizaria a sua utilização, segundo a avaliação de Maquiavel. A sua leitura dos dados históricos foi dirigida pela preocupação de evidenciar os exemplos que corroboravam as regras e máximas que orientavam a ação políica. A compreensão dessas regras ampliava o conhecimento dos meios tornando-os operacionais para os agentes políticos. Graças a isso, o comportamento humano tornava-se mais previsível, aumentando as chances de êxito e reduzindo o risco do fracasso.

Controlar a regularidade histórica significa, para Maquiavel, conhecer e tirar proveito da exigência de êxito na ação política: quanto mais esta ação for orientada pelo conhecimento histórico, tanto mais racional será, isto é, mais eficaz. 0 motivo pelo qual Maquiavel quer que a ação seja orientada pelo conhecimento histórico é que, dessa maneira, será possível reduzir a influência da fortuna sob o agir humano. Desse modo, pode-se dizer que o conhecimento histórico é concebido como mediador de uma estratégia de êxito político: os fatos são selecionados em vista da preocupação de apontar no presente a estratégia de ação mais apropriada para gear efeitos positivos no futuro.

\section{O Sentido da Imitação dos Antigos}

0 tema da imitação dos antigos responde à mesma exigência do conhecimento histórico: a necessidade de obter êxito na ação política. Para Maquiavel, o conceito de imitação não se restringe a uma noção puramente teórica. Não se trata de um mero saber acerca das instituições e dos acontecimentos da Antigüidade. 0 que évisado por Maquiavel é um conhecimento prático, um saber capaz de levar os agentes políicos a adotarem procedimentos adequados à condução do Estado. Para tanto, épreciso modificar a maneira 
de ler a história antiga. Certamente, enquanto os homens permanecerem presos à compreensão da história como um conjunto de fábulas mitológicas maravilhosas de um outro mundo, só será possível julgar a imitação "mais do que difícil, impossivel" (Discorsi I, Introdução).

Maquiavel não concordava com isso. Considerar a imitação impossível seria tão absurdo quanto pensar que "o sol, o céu, os elementos, os homens tivessem alterado seus movimentos, sua ordem e seu poder em relação ao que eram nos tempos antigos" (Discorsi I, Introduçăo). Contudo, pode-se defender uma imitação da Antigüidade fundada unicamente na afirmação categórica da imutabilidade do homem e da natureza? Tal atitude não conduz à negação da história ou ao seu absurdo, uma vez que, se nada muda, a imitação seria possível, mas inútil? Podemos dizer que a tese da imutabilidade dos elementos físicos e da natureza humana é, certamente, um dos fundamentos da imitação da Antigüidade. No entanto, Maquiavel aponta commais precisão paraum outro pilar: a legitimidade da admiração pelo passado. A admiração dos antigos é uma atitude louvável, mas exige discernimento. Seria preciso identificar no tempo do autor a existência ou inexistênciadosvalores queorientaram os Estados naAntigüidade: "os homens louvam sempre, embora nem sempre com razão, os tempos antigos e criticam os presentes; são de tal modo partidários das coisas passadas que não só celebram aquelas épocas que são conhecidas por nós graças às lembranças que nos deixaram delas os escritores, mas inclusive aquelas que, sendo já velhas, recordam terem visto em sua juventude". (Discorsi II, Introdução).

A atitude de louvar o passado e criticar o presente deve ser reprovada, segundo Maquiavel, numa situação específica: quando estamos diante de um governo, de um bom governo. Vejamos o exemplo que segue: "suponhamos uma cidade ou uma província organizada politicamente por um homem excelente que, por certo tempo, graças à virtù de seu organizador, fez grandes progressos. Quem nascesse em tal Estado, e louvasse mais os tempos antigos do que os modernos, se enganaria" (Discorsi II, Introdução). Contudo, quem "nascer depois naquela cidade ou país, quando tiver chegado o tempo de seu declínio, não se enganará" (Discorsi II, Introdução) se louvar o passado e condenar o presente. Nessa situação está, por exemplo, "quem nasceu na Itália ou na Grécia e não se converteu em ultramontano se é da Itália ou em turco se é grego" (Discorsi II, Introdução). Aquele que vive num desses países nesta época de decadência, "tem razão em censurar os seus tempos e louvar os antigos" (Discorsi II, Introdução). Embora louvar o passado e se queixar do presente seja uma atitude recomendada para aqueles que viveram na Itália ao tempo de Maquiavel, o mesmo não se aplica, por exemplo, aos contemporâneos que viveram no reino da França, no império turco, ou na multifacetada Alemanha: "em todas estas províncias, em todas estas seitas, residiu a virtù depois que os romanos se 
arruinaram e ainda se conserva em boa parte delas, é desejada e elogiada com sincero louvor. Quem nasce em alguma destas e louva os tempos passados mais do que os presentes, pode ser que se engane". (Discorsi II, Introdução).

A admiração da Antigüidade deve ser relativizada em favor de um discernimento do quadro presente, de sua adequação ou não aos valores antigos. 0 segundo pilar da imitação dos antigos, a afirmação da imutabilidade de homem e natureza, deve ser relativizado em favor da variação contínua dos acontecimentos e das diferenças de educação. Maquiavel argumenta que duvidar da possibilidade da imitação dos antigos seria algo tão absurdo quanto pensar que "o céu, o sol, os elementos e os homens tivessem variado seus movimentos, sua ordem e seu poder" (Discorsi I, Introdução). No entanto, ele ameniza progressivamente essa visão mecânica em favor daquela que sustenta a variação permanente da natureza e das circunstâncias. Assim, ainda no livro I dos Discorsi, ao mesmo tempo em que funda a possibilidade da imitação numa espécie de invariabilidade da natureza física e humana, já que a história, segundo ele, revelaria que "todas as cidades e todos os povos têm os mesmos desejos e os mesmos umori eassim tem sido sempre" (Discorsi I, 39), acrescenta no mesmo argumento que a imitação consiste não só na proposição de "remédios já utilizados pelos antigos" (Discorsi I, 39), como também na formulação de "novos baseados na semelhança dos acontecimentos" (Discorsi I, 39). Embora os desejos e os umori possam repetir-se, a ação política requer sempre uma solução singular, tenha ela sido jáinventada ou não. A história deve, pois, ser pensada sob esse duplo aspecto: da identidade (de desejos e umori) e da diferença (dos acontecimentos concretos). A repetição (imutabilidade) é capaz de proporcionar lições práticas somente para aquele que se referisse constantemente à singularidade dos acontecimentos.

Quando temos presente isso, resulta indevida a crítica que seu amigo Francesco Guicciardini fez à sua concepção de imitação: "Como se enganam os que a cada palavra alegam os romanos! Seria preciso uma cidade como era a deles, e depois governar segundo aquele exemplo, o qual, para quem tem qualidades desproporcionais, étão desproporcional quanto querer que 0 asno corra como um cavalo" ${ }^{3}$ Com as polêmicas palavras finais, Guicciardini aponta para a diferença fundamental entre os pressupostos da vida antigae moderna e aniquila, desde os seus princípios, a perspectiva histórica da unidade das duas épocas, tirando o fundamento da compreensão de imitação no sentido tradicional. 0 que chama a atenção é, sobretudo, o fato de Guicciardini apontar somente para as premissas teóricas subjacentes à imitação pregada por Maquiavel quando a preocupação deste não é esta, mas o interesse prático de extrair lições úteis da história como meios para

3 Guicciardini, Francesco. Reflexões (Ricordi). São Paulo, Hucitec, 1985, p. $96-7$ (Ricordo n0 110). 
transformar a situação atual.

Para compreender o segundo aspecto, a influência da educação na variação do comportamento humano, é preciso apontar, primeiramente, para o sentido específico que a imitação tem para Maquiavel. 0 que está em primeiro plano não é o problema teórico que a imitação implica, mas o interesse em corrigir a decadência de sua própria época apoiando-se no modelo dos antigos. A imitação destes se impõe num quadro de corrupção moral como o da Itália, no qual "a virtude que reinava naqueles tempos [da Roma antiga] e o vício que reina agora [são] mais evidentes do que o sol" (Discorsi II, Introdução). Num contexto desses, "o dever do homem bom é ensinar aos outros o bem que não pôde colocar em prática devido à maldade dos tempos ou da fortuna" (Discorsi II, Introdução). É isso, confessa Maquiavel, "que me anima a dizer manifestamente 0 que penso daqueles tempos e destes, de modo que os espíritos dos jovens que lerem estes meus escritos fujam destes e disponham-se a imitar aqueles, tão logo a fortuna lhes dê ocasião de fazê-lo" (Discorsi II, Introdução). No primeiro nível do problema da imitação não está uma preocupação teórica (como é o caso de Guicciardini, por exemplo), mas prática, imposta pela consciência de um "homem bom" que o obriga a "ensinar aos outros o bem": educar as pessoas a "imitar as virtudes" dos antigos e a "fugir dos vícios" dos tempos presentes.

Em segundo lugar, a necessidade de ter de pensar o novo pela semelhança com os acontecimentos antigos revela que o modelo de ação atual não é evidente por si mesmo, mas é resultado de uma análise, devendo, por vezes, o remédio de hoje ser o oposto do utilizado ontem. Maquiavel ilustra essa possibilidade ao destacar dois exemplos, um moderno e outro antigo. 0 primeiro caso é o de Florença na oportunidade em que, forçada a fazer guerra contra os Estados que haviam se apropriado de algumas de suas possessões, o que aumentou suas despesas, viu-se obrigada a elevar os impostos, causando insatisfação popular. Não compreendendo a necessidade da guerra e das despesas que esta provocava, o povo passou a atribuir a causa disso exclusivamente ao Conselho dos Dez da Guerra encarregado de conduzi-la. Chegada a época de sua eleição, não os reelegeu. Esta decisão, conclui Maquiavel, "foi tão perniciosa que não só não terminou com a guerra, como todos queriam, como também afastou os homens que poderiam levá-la a cabo com prudência, o que causou tantas desordens que, além de Pisa, (Florença) perdeu Arezzo e muitos outros lugares, de modo que o povo tomou consciência de seu erro, e como a causa do mal era a febre e não o médico, voltou a instituir a magistratura dos Dez". (Discorsi I, 39).

Situação análoga atravessou o povo romano ao atribuir aos cônsules a responsabilidade pelas privações ocasionadas pela guerra. 0 povo, considerando-os culpados 
pelos sacrifícios que a guerra implicava, decidiu abolir o consulado, restabelecendo-o apenas bem mais tarde, a tomar consciência do perigo desta decisão. 0 que Maquiavel parece querer dizer com este exemplo é o seguinte: tivesse o povo de Florença feito um uso adequado da história, não teria cometido o erro de não reeleger os Dez da Guerra. Os florentinos, encontrando-se em situação análoga ao precedente romano, tinham como prever as consequiências de uma decisão como essa que tomaram. Teria bastado extrair a lição do caso romano: evitar a medida adotada por estes, pois também eles haviam pensado que a causa do mal era o "médico" (isto é, as pessoas encarregadas de conduzir a guerra) e não a "febre" (quer dizer, as exigências impostas pela guerra). Neste caso, 0 exemplo histórico ensinava a não agir do modo como os antigos agiram. Isto é, as circunstâncias exigiam a invenção de novos remédios, ainda que fundamentadas na semelhança dos acontecimentos.

Em terceiro lugar, o argumento de que "os homens sempre tiveram e terão as mesmas paixões" (Discorsi III, 43), muitas vezes aduzido para fundamentar a opinião generalizada de que Maquiavel defenderia uma uniformidade antropológica, deve ser lido à luz da conclusão dessa mesma passagem: "a educação modelou o modo de vida dos povos" (Discorsi III, 43). Embora as paixões inerentes à natureza humana possam ser as mesmas, não são, porém, inalteráveis, mas moldáveis pela educação, perpetuando-se e enraizando-se nos povos e indivíduos, constituindo-se numa espécie de "segunda natureza".

Como podemos notar, a noção maquiaveliana de imitação está longe de ser a repetição mecânica, no presente, de ações plenas de êxito do passado, como à primeira vista poderíamos depreender da leitura da Introdução ao livro I dos Discorsi. Antes, estamos diante de um certo relativismo histórico: não podemos concluir da invariabilidade das leis naturais que regem o céu, o movimento do sol e os elementos do comportamento humano uma eterna identidade e imutabilidade da natureza e do homem. Com efeito, assim como o sol não brilha em toda parte e sempre com o mesmo vigor, os elementos naturais não se manifestam em toda parte e sempre de maneira idêntica, a topografia não é sempre a mesma, do mesmo modo também os homens mudam, tanto de um país e família a outros, quanto de uma época a outra. Este paradoxo, o da instabilidade no equilibrio, remete, em última análise, àquilo que em linguagem moderna poderíamos chamar de oposição entre cultura e natureza. Há, no entendimento de Maquiavel, um substrato psicológico permanente na natureza humana. No entanto, esse substrato é modelado e remodelado de modo mais ou menos permanente de acordo com as condições de existência, e a influência da educação.

A constatação de que reside no passado um modelo válido para a atualidade encontra apoio na premissa de uma natureza humana invariável. Contudo, essa 
pressuposição é ultrapassada pela idéia de que a virtù é ativada diversamente no curso da história. Isto é, que existem épocas nas quais há uma realização plena da virtù e aquelas nas quais ela praticamente inexiste. Essas diferenças tornam-se possíveis, porque a mesma natureza humana sempre se concretiza "segundo a forma da educação" numa determinada modalidade e, por isso, também dá origem cada vez a um outro e novo modo de viver; isto é, a estruturas comportamentais que não podemos fazer coincidir umas com as outras.

Diante desse quadro, o que pode significar "imitação da Antigüidade" para Maquiavel? Certamente não um simples retorno ao antigo. Antes, Maquiavel mostra que esse retorno implica numa re-elaboração daquilo que foi identificado como antigo. Assim, a ação a ser imitada não é mais a única coisa a considerar: é preciso confrontar, antes de tudo, o conjunto das circunstâncias e finalidades passadas com as do presente. Nesse sentido, imitar consiste menos em reproduzir tão precisamente quanto possível uma ação passada, quanto em aplicar sensatamente ao presente e ao futuro a lição extraída do passado. É esse o sentido que Maquiavel reforça na passagem já anteriormente referida: "para quem examina diligentemente as coisas passadas, éfácil prever as futuras em qualquer república, e aplicar os remédios empregados pelos antigos, ou, se não encontra nenhum usado por eles, pensar em novos levando em conta a semelhança das circunstâncias" (Discorsi I, 39).

Na medida em que é preciso "pensar em novos [remédios] levando em conta a semelhança das circunstâncias", a imitação não pode mais ser considerada um "remédio" miraculoso para todos os males atuais e futuros. Muito antes, é tão somente uma das soluções possíveis que pode nos levar a adotá-la ou a seguir um sentido contrário. Esta conclusão poderia, à primeira vista, nos levar a pensar que se trata de uma recusa, ou ao menos, de uma depreciação da imitação. Na verdade, trata-se apenas de chamar a atenção para o fato de que não se deve repetir mecanicamente as ações dos dirigentes políticos da Antigüidade. É preciso avaliá-las no seu contexto, tirar a lição dos fatos mais do que dos homens e aplicar as lições, mantidas as devidas proporções, às situações presentes efuturas.

Assim, o princípio enquanto tal da imitação não é negado, nem o poderia ser, na medida em que a permanência e a recorrência dos mesmos fenômenos continuam a ser consideradas por Maquiavel como leis gerais. Quer dizer, a natureza das coisas e do homem contêm elementos constantes que produzem necessariamente o retorno dos mesmos efeitos que, sendo adequados ou inadequados, exigem necessariamente meios análogos para os assumir ou evitar. Esta conclusão permite perceber que não há contradição entre a teoria da imitação e o papel da fortuna em Maquiavel. A imitação dos grandes 
exemplos da Antigüidade permanece uma das armas, talvez a principal, das quais a virtù dispõe na luta contra a fortuna e suas incessantes variações. 0 que Maquiavel destaca claramente é que os mesmos remédios não produzem sempre os mesmos resultados: pode-se chegar ao mesmo objetivo por vias diferentes, como também seguindo caminhos iguais. Um personagem pode obter êxito onde 0 outro fracassa. Tudo depende das circunstâncias e da capacidade de adaptação a elas.

A compreensão dessa regra geral fica clara no exame que Maquiavel faz do problema do uso da clemência e da crueldade pelos comandantes na guerra. Numa formulação geral, o problema central consiste no seguinte: como é possível que, com meios opostos, se alcancem resultados iguais? 0 importante nessa constatação é o fato de se inverter os termos da resposta comumente dada. Talvez, pondera Maquiavel, não dependa daqueles fatores considerados em geral como decisivos, o emprego da crueldade e da clemência. Quer dizer, o decisivo talvez não esteja no uso de meios cruéis ou humanos, e sim na capacidade de liderar as tropas, na virtù do comandante. 0 problema formulado desta maneiraéilustrado pela oposição entre o modo de agir de Aníbal e de Cipião. Aníbal é conhecido por sua extrema crueldade e Cipião por sua grande humanidade. Comum a ambos, sob premissas tão opostas, está o resultado igual. A explicação do fato está na elevada virtù dos dois comandantes: "concluo, portanto, que não importa muito de que modo um capitão age, desde que sua virtù seja tão grande que compense qualquer dos dois comportamentos" (Discorsi III, 21).

Assim, aquilo que, graças à história, épercebido como necessário e constante não pode ser atribuído, a priori, à baixeza dos homens, mas à essencial indeterminação humana. Isso exige que o dirigente político empregue meios de controle da ordem pública sempre adequados à singularidade das circunstâncias. Numa tal perspectiva, a história antiga deixa de oferecer o modelo absoluto de toda ação política eficaz, sem deixar de ser a sua fonte. 0 que o político de virtù encontra na Antigüidade não são exemplos de conduta acabados e prontos para serem assumidos, mas um amplo quadro de comportamentos e de situações humanas capazes de esclarecer e corroborar as regras gerais que comandam a política.

No início dos Discorsi, Maquiavel convida os leitores a buscar o verdadeiro conhecimento da história, extraindo de exemplos antigos a seiva que nutre os casos modernos. Este programa é possível, porque há certa regularidade (constância ou estabilidade) nos comportamentos humanos, apesar da variação ou instabilidade dos acontecimentos e as diferenças resultantes da educação dos indivíduos. Convenientemente compreendido, o comportamento político do homemécomparável a um processo natural: 
nele se encontram as mesmas alternâncias de nascimento e morte, tanto do indivíduo quanto do Estado (corpo misto). Assim como é possível descrever e esclarecer as regularidades e as leis dos fenômenos físicos, assim também a arte política deve poder esclarecer as leis dos corpos mistos, de modo que seus dirigentes empreendam, na realidade efetiva, as medidas mais adequadas à realização dos fins propostos.

\section{O Problema da Mudança Histórica}

A compreensão da idéia maquiaveliana do devir histórico remete para algumas notas de sua compreensão de homem. Com efeito, por que os homens agem? Isto é, o que explica o fato de eles se moverem, incansavelmente? Para Maquiavel, isto se explica porque o homem é um ser movido pelo desejo: "a natureza criou os homens de maneira que podem desejar tudo, mas não podem conseguir tudo, de modo que, sendo sempre maior o desejo do que a capacidade de conseguir resulta o descontentamento do que se possui e a insatisfação em relação a isso. Daí nasce a variação de suas fortunas" (Discorsi I, 37). O homemé capaz de desejar muito mais do queécapaz de concretizar. A insatisfação, isto é, o fato de, literalmente, não estar saciado, de ser incapaz, por definição, de encontrar algo que aplaque plenamente seu desejo, é o que possibilita e provoca, do ponto de vista antropológico, o movimento humano de busca e de transformação.

Um segundo aspecto que merece ser citado é o caráter natural do homem. Quer dizer, o comportamento histórico dos homens é sempre similar: é regular e uniforme: "para quem considera as coisas presentes e antigas, descobre facilmente que em todas as cidades, e em todos os povos existem os mesmos desejos e os mesmos umori, e assim foi sempre" (Discorsi I, 39). A identidade dos impulsos vitais origina reações semelhantes, que se repetem não somente porque respondem a impulsos idênticos, mas também porque o homem procura imitar a conduta já seguida por outros, como vimos acima.

A regularidade e uniformidade dos desejos e paixões humanas fornecem um argumento importante para aqueles que pretendem encontrar em Maquiavel um seguidor da teoria cíclica da história. Essa hipótese é reforçada pela leitura do segundo capítulo do primeiro livro dos Discorsi. Esta passagem parece indicar que Maquiavel compartilha efetivamente com alguns autores clássicos, particularmente Políbio, ${ }^{4}$ da concepção circular de história. Em princípio, podemos dizer que a adesão de Maquiavel à teoria cíclica de Políbio foi apenas parcial. Se ele diz, tal como o historiador grego, que o tempo

4 PoLííns. História. Brasília: Editora UnB, 1996. Nas passagens que referiremos desta obra, o número em romano que segue ao título corresponde ao do livro e aquele em arábico ao do capítulo. 
é cíclico, também nuança de tal forma essa afirmação que a circularidade perde completamente sua finalidade de previsão do movimento histórico que possuía em Polibio, não se prestando mais como instrumento de desvelamento do real. Vamos examinar algumas passagens-chave desses dois pensadores para evidenciar melhor essa afirmação. A passagem central dos Discorsi é a seguinte:

Para esclarecer quais foram os ordenamentos da cidade de Roma, e quais circunstâncias levaram à sua perfeição, lembrarei que alguns escreveram, referindose ao governo, que este pode ser de três tipos: Principato, Ottimati e Popolare [...]. Outros, e segundo a opinião de muitos, mais sábios, acham que os tipos de governo são seis, dos quais três são péssimos e os outros três são bons em si mesmos, mas se corrompem tão facilmente que chegam a se tornar perniciosos. Os bons são os relacionados acima; os maus, outros três e cada um deles é de tal modo semelhante àquele que lhe está próximo, que facilmente saltam de um a outro: porque 0 Principato facilmente se torna tirannico; os Ottimati com facilidade se transformam em stato di pocbi, e o Popolare se converte sem dificuldade em licenzioso. De modo que, se um legislador ordena a cidade segundo um dos três Estados [bons], o faz por pouco tempo, porque nenhum remédio é capaz de evitar que se precipite no seu contrário, pela semelhança que tem neste assunto a virtude e o vício (Discorsi I, 2).

Comparemos este trecho com a passagem correspondente de Políbio, da qual parece quase uma paráfrase:

A maioria dos autores cujo objetivo é instruir-nos sistematicamente a respeito das constituições distingue três espécies das mesmas, dando a uma delas o nome de monárquica, a outra o nome de aristocrática e à terceira o de democrática (História VI, 4) [...]. Devemos portanto afirmar que há seis espécies de governo: as três mencionadas inicialmente, faladas por todas as bocas, e as três naturalmente afins a elas, quero dizer a autocracia, a oligarquia e a oclocracia. A primeira de todas essas espécies a aparecer foi a autocracia, cujo surgimento é espontâneo e natural; em seguida nasceu a monarquia, derivada da autocracia por evolução e pela correção de defeitos. Esta se transmuda em sua forma afim degenerada, quero dizer a tirania, e em seguida à dissolução de ambas é gerada a aristocracia. Esta degenera por sua própria natureza em oligarquia, e quando a maioria, inflamada pelo ressentimento, vinga-se desse governo por causa das injustiças cometidas pelos detentores do poder, é gerada a democracia; finalmente, da violência e do desprezo à lei inerentes a esta resulta no devido tempo a oclocracia (História VI, 4). 
À primeira vista, Maquiavel assume plenamente a teoria cíclica na medida em que confessa que o governante que adota alguma das três formas "boas" de governo não tem como mantê-la, porque não há como impedir que ela se precipite na sua forma contrária, tal a semelhança entre a forma boa e a má. No entanto, se observarmos mais atentamente os termos utilizados por um e por outro, perceberemos uma diferença essencial: enquanto a preocupação de Políbio é mostrar que a teoria cíclica se presta para descobrir o processo teórico de degeneraçãoregeneração dos Estados, Maquiavel parece não dar maior importância, nem à circularidade, nem à classificação em formas boas e más. Para Polibio, a teoria dos ciclos é um instrumento precioso para a descrição das diversas etapas que as constituições políticas necessariamente percorrem, permitindo, ao mesmo tempo a previsão: "Esse é o ciclo pelo qual passam as constituições, o curso natural de suas transformações, de sua desaparição e de seu retorno ao ponto de partida. Quem distinguir nitidamente esse ciclo poderá, falando do futuro de qualquer forma de governo, enganar-se em sua estimativa da duração do processo, mas se seu juízo não for afetado pela animosidade ou pelo despeito dificilmente se equivocará quanto ao seu estágio de crescimento ou declínio e quanto à forma que resultará desse processo". (História VI, 9).

Uma vez identificado o estágio no qual se encontra a evolução de determinada forma de Estado, será possível antecipar com precisão a etapa seguinte, porque a sucessão élinear e preestabelecida. Podemos enganar-nos acerca do tempo que determinada etapa leva para ser superada pela seguinte, mas de modo algum sobre "a forma que resultará desse processo". ${ }^{5}$ Maquiavel, ao invés disso, parece quebrar essa sequiência fechada da circularidade polibiana, eximindo-se de extrair dela o poder de prever o futuro: "Esteéo círculo em que giram todas as repúblicas, se governem ou sejam governadas; mas raramente retornam às mesmas formas políticas, porque quase nenhuma república pode ter uma vida tão longa que possa passar muitas vezes esta série de mutações e permanecer em pé. Antes pode acontecer que, em meio a estes distúrbios, uma república, privada de conselho e força, se torne súdita de algum Estado vizinho mais bem organizado do que ela, mas se não sucedesse isso, um país poderia dar voltas por tempo infinito na roda das formas de governo". (Discorsi I, 2).

5 De acordo com a teoria polibiana da circularidade, o sentido da história é imutável. Esquematicamente, de acordo com a passagem citada acima, teríamos o seguinte: animalidade total $\Rightarrow$ autocracia $\Rightarrow$ monarquia $\Rightarrow$ tirania $\Rightarrow$ aristocracia $\Rightarrow$ oligarquia $\Rightarrow$ democracia $\Rightarrow$ oclocracia $\Rightarrow$ (animalidade total $) \Rightarrow$ autocracia $\Rightarrow \ldots$. 
A idéia de Políbio, de que os ciclos se repetem infinitamente, é desmentida pela realidade concreta na qual os Estados se movem, "porque quase nenhuma república pode passar muitas vezes esta série de mutações e permanecer de pé". 0 que Maquiavel parece questionar é a possibilidade de um Estado possuir força própria suficiente para iniciar um novo ciclo depois que chegou ao estágio mais baixo de sua degeneração, como Políbio imagina. Ao invés disso, pondera Maquiavel, o mais provável é que uma forma política que tenha chegado a esse extremo "se torne súdita de algum Estado vizinho melhor organizado". Em assim sendo, não ocorrerá um retorno a ponto de partida no âmbito do mesmo Estado, esim uma transferência de domínio de um Estado para outro. Ora, se pelo motivo exposto um Estado não reinicia necessariamente um novo ciclo, como pensava Polỉio, a teoria da circularidade perde sua utilidade explicativa da sucessão histórica e a sua capacidade de antecipar os acontecimentos.

A pouca importância que Maquiavel parece conferir à tripartição clássica (e suas correspondentes formas corrompidas) é reforçada pelo fato de encontrarmos nos capítulos seguintes a este que estamos examinando, a mesma bipolarização de monarquia e república existente em $O$ Príncipe. Não só encontramos nos demais capítulos dos Discorsi liberdade contraposta a principado (e à tirania), como também o autor opõe ou associa constantemente república e principado, sem preocupar-se, tal como em 0 Príncipe, em distinguir os diversos tipos de governos colegiados referidos no segundo capítulo dos Discorsi.

Se a teoria cíclica é abandonada por Maquiavel pelas razões expostas, o mesmo acontece com a distinção clássica entre regimes políticos virtuosos e corrompidos: "digo, pois, que todas estas formas sãopestiferi, as três boas, por causa da brevidade de suas vidas, as três más pela malignidade que há nelas" (Discorsi I , 2). Para ser mais exato, o que Maquiavel parece contestar não é a pertinência da distinção clássica como tal, já que testemunha respeito à "opinião geral mais sábia" (Discorsi I, 2) que acredita nisso. 0 descabido, na sua avaliação, é a idéia de que possam existir regimes bons e maus em si. Apriori nenhuma forma de governo pode merecer esta classificação: para as consideradas boas é indevida, porque são instáveis; para as tidas como más é improcedente, porque destroem a vida coletiva.

0 exame da seqüência das constituições nos permitiu tirar duas lições. A primeira, que a idéia de formas constitucionais que se sucedem ciclicamente de modo infinito não encontra apoio na realidade. A segunda, que a distinção entre formas a priori boas e más é destituída de sentido. Quanto à forma de governo mais apropriada, a refutação da distinção clássica não faz com que Maquiavel jogue todas numa vala comum. 0 Estado 
tirannico, o stato di pochi e o licenzioso são a própria negação da vida política e, por isso, rigorosamente sequer poderiam ser chamadas de formas de governo. Em termos ideais, o melhor parece ser uma mistura das três formas boas: "todos aqueles que ordenam prudentemente as leis, conhecendo este defeito, fogem de cada uma destas formas em si mesmas, escolhendo uma na qual participem todas, julgando-a mais firme e mais estável, pois assim um poder controla o outro, e numa mesma cidade se mesclam 0 Principato, os Ottimati e o Governo Popolare". (Discorsi I, 2).

Na prática, porém, trata-se semprede instaurar ou uma república ou um principado. 0 principado é a única alternativa nas situações de extrema crise: num quadro de corrupção generalizada das instituições não há como esperar que estas tenham ainda força suficiente para promover a restauração do Estado. Quando ordini e leggi perderam sua força, a única esperança de reforma do Estado está na intervenção de um indivíduo dotado de uma virtù extraordinária. No entanto, a escolha do regime mais apropriado em vista do grau de corrupção vigente não é deixada a uma apreciação pessoal. As intenções do dirigente esuas preferências pessoais por uma ou outra forma de governo estão submetidas às possibilidades objetivas oferecidas pela realidade vigente. As características peculiares desta substituem as tendências individuais na determinação da solução objetivamente desejável e concretamente viável. Se, apesar disso, o governante quiser a toda força ir de encontro à realidade "fará algo sem proporção e pouco durável" (Discorsi I, 55).

Assim, podemos dizer que, para Maquiavel, diferentemente de Políbio, uma forma de governo não alcança a sua perfeição ao termo da evolução de um ciclo regular da história, e sim quando está adequada à "natureza dos tempos" (qualità de' tempi). A teoria cíclica perde sua finalidade de previsão (que possuía em Polibio) para tornar-se um recurso que possibilita pensar a história dos Estados como um movimento que se caracteriza sempre por uma evolução da unidade (pela ação de um príncipe fundador) à multiplicidade (pela formação de governos colegiados), seguido de um retorno regenerador à unidade inicial todas as vezes que 0 Estado se corrompe e se transforma em licenzioso.

\section{A Decadência e a RegeneraÇão dos Estados}

As considerações acima evidenciam que não há uma oposição irredutível entre principado e república. Um e outro representam dois momentos sucessivos e não contraditórios de um mesmo processo. 0 principado, longe de constituir um fim em si mesmo, é somente a etapa inicial, a base propriamente dita de nascimento ou de renascimento do Estado: uma fase inicial necessária entre as trevas da anarquia, que 
ronda os Estados corrompidos, e a república. Esta conclusão não é derivada da teoria da circularidade histórica de Políbio, particularmente da sua tese das alternâncias de corrupção e renascimento dos Estados, e sim da observação histórica de como os Estados se formam, desenvolvem e decaem. Para concluir nossa análise acerca da idéia maquiaveliana de história, vamos tecer algumas breves considerações sobre esse tema. A tese de Maquiavel em relação aos Estadosé a de que "são salutares aquelas alterações que os reconduzem aos seus princípios. Por isso, estão mais bem organizados e têm uma vida mais longa os que, mediante suas instituições, podem renovar-se freqüentemente, ou aqueles que, por qualquer circunstância externa às suas instituições, chegam à dita renovaçãa". (Discorsi III, 1).

Pesando sobre o Estado a fatalidade de uma decadência orgânica, é necessário que, de tempos em tempos, este sofra um processo de rejuvenescimento e purificação de seus costumese instituições. Istoé chamado por Maquiavel de reduzione verso ilprincipio. 0 sintoma da decadência é o desaparecimento do ideal do bem comum e o crescimento das lutas das facções pela conquista do poder, que subordinam o interesse público ao privado. Isso faz com que aquilo que constituía a sua força originária desapareça e surja em seu lugar a licenza. Nesta situação, ou o Estado se renova sob a pressão de uma ameaça externa ou encontra em si mesmo forças ainda suficientemente sãs, suas instituições ou um reformador de virtù excepcional, para reagir contra a decadência e recuperar o vigor primitivo.

Não somente as repúblicas, quando se corrompem, precisam retornar ao seu princípio "graças ao qual recobrarão sua primitiva reputação e sua capacidade de crescimento" (Discorsi III, 1), mas as próprias monarquias têm necessidade de voltar a esse "impulso original". Ora, quando tanto repúblicas (formas múltiplas de governo), quanto monarquias (formas unas de governo) precisam tornar ao seu princípio, está eliminada a idéia de degeneração e renascimento progressivo e linear das formas políticas, como ensina a teoria polibiana da circularidade (História VI, 9). Maquiavel quebra 0 círculo e considera os regimes isoladamente num movimento pendular que vai da miséria radical do terror e da penúria originais até o momento em que, tendo atingido o seu auge, inelutavelmente todos os Estados declinam: "A este propósito, diziam os que governaram o Estado de Florença desde 1434 até 1494, que era necessário renovar 0 governo a cada cinco anos, pois de outro modo resultava difícil mantê-lo. Chamavam renovar o governo encher de terror e de medo os homens que colocavam nele, castigando os que o haviam exercido anteriormente se, segundo seu parecer e segundo aquele regime, haviam agido mal. Mas como daqueles castigos a memória se esquece, os homens cobram 
ânimo para intentar coisas novas e para falar mal, e, por isso, é necessário prevenir os males voltando o Estado aos seus princípios". (Discorsi III, 1).

Este movimento pendular não é cíclico no sentido estrito em que o entende Polỉio, mas está submetido aos acidentes extrínsecos e ao acaso: "esta redução ao princípio pode ocorrer ou por acidente ex:rínseco ou por prudência intrínseca" (Discorsi III, 1). Essa observação permite-nos concluir que os dois regimes, república e monarquia, têm as mesmas chances de perdurar, desde que saibam retornar ao seu princípio. Assim, podemos dizer que não é mais a marcha majestosa das constituições através dos séculos, e sim que éunicamente um movimento pendular curto e acelerado que pode assegurar a ressurreição contínua dos corpos políticos. Para Maquiavel, não se trata mais da evolução necessária de uma forma de governo determinada para uma seguinte mais perfeita, e sim de reavivar periodicamente o terror originário, como ele confessa nesta passagem: "Entre uma e outra de semelhantes execuções, não deve transcorrer um espaço maior do que dez anos, já que, passado esse tempo, os homens começam a mudar os costumes e a transgredir as leis, e se não acontece nada que traga à sua memória o castigo e renove em seus espíritos o temor, rapidamente se juntam tantos delinqüentes que já não será possível castigá-los sem perigo". (Discorsi III, 1).

Como podemos notar, Políbio oferece para Maquiavel apenas um esquema a partir do qual este molda o seu próprio ensinamento claramente afastado do sentido clássico da teoria cíclica. Este afastamento pode ser confirmado também na História de Florença, quando trata do tema dos ciclos constitucionais e os descreve levando em consideração a oposição entre "ordem" e "desordem": "Costumam os países, o mais das vezes, nas mudanças a que são submetidos, da ordem vir à desordem, e novamente depois passar da desordem à ordem: porque não estando na natureza das coisas deste mundo o deter-se, quando chegam à sua máxima perfeição, não mais podendo se elevar convém que se precipitem; e de igual maneira, uma vez caídos e pelas desordens chegados à máxima baixeza, necessariamente não podendo mais cair, convém que se elevem: assim, sempre do bem se cai no mal e do mal eleva-se ao bem". (História de Florença V, 1). ${ }^{6}$

Este fluxo e refluxo não implica, porém, num determinismo capaz de conduzir Maquiavel a renunciar à idéia da fundação contínua defendida nos Discorsi. 0 que ele ressaltaéa importância da ação humana na construção dos destinos da cidade. 0 domínio político não consiste em se deixar levar por este fluxo e refluxo, nem em querer impedilo. Consiste antes em acelerá-lo a fim de que a ociosidade não tenha tempo de se expandir

Machiaveli, Niccolò. Istorie Fiorentine. In: Tutte le Opere. Firenze, Sansoni, 1992, p. 629-844. Nas próximas referências a esta obra, o número em romano corresponde ao do livro e aquele em arábico ao do capítulo. 
e a glória e a prosperidade sejam reafirmadas sem cessar. Para Maquiavel, a teoria dos ciclos não significa uma teoria científica capaz de descrever as diferentes etapas do desenvolvimento humano e fazer a sua previsão, como afirmava Políbio. 0 historiador de Florença, contrariamente ao que pretendia o historiador grego, não tem o propósito de deduzir uma lei universal da observação minuciosa das instituições políticas. Ele não aceita a idéia de um círculo constitucional, a idéia de uma repetitividade regular e cíclica das formas de governo, menos ainda o poder profético que esta teoria tem em Políbio. Ao invés disso, de um ciclo ou movimento perfeito e bem regulado, passa-se para um ciclo desordenado capaz de ser acelerado ou retardado. Conseqüentemente, não podemos falar numa circularidade histórica.

Maquiavel afasta-se igualmente da idéia agostiniana da existência de uma finalidade predeterminada para a qual se encaminharia o movimento das ações humanas. Não havendo uma finalidade histórica previamente estabelecida, também não pode haver a possibilidade de um progresso definitivo da história. A marcha das coisas humanas, quaisquer que sejam os seus altos e baixos, não altera em nada o estado do mundo. A quantidade estável de bem e de mal pode apenas distribuir-se no espaço e no tempo sem que um termo possa eliminar o outro e crescer infinitamente: "Refletindo sobre a maneira como as coisas acontecem, penso que se produzem sempre do mesmo modo, e que sempre há a mesma quantidade de bem e de mal, mas que este bem e este mal muda de província em província, o que podemos ver pelo que se conhece dos impérios antigos, que mudavam de um lugar para outro pela variação dos costumes, mas o mundo permanecia o mesmo". (Discorsi II, Introdução).

A imutabilidade do mundo, afirmada nesta passagem, significa simplesmente que sempre é possível esperar que a ação humana seja capaz de recriar as condições necessárias para o surgimento de sociedades fortes e livres. Adecadência de um Estado não é nada mais do que a condição necessária para o surgimento de um novo poder e não a seta que indica um rumo (finalidade necessária do curso histórico) e muito menos que esse rumo seja progressivo: realização no tempo de uma vontade eterna. Em suma, apesar da amplitude de seus empréstimos à História de Polỉio, é evidente que Maquiavel não deixa de reinterpretar largamente os seus dados e de ajustar as idéias do historiador grego ao seu próprio pensamento. Parodiando os termos da carta escrita ao seu amigo Vettori, poderíamos dizer que Maquiavel não acolhe passivamente a lição de Políbio, mas "conversa" com ele de igual para igual. Os pensamentos dos quais se serve são tanto simples empréstimos quanto frutos da confrontação de experiências e de idéias. 0 fato evidenteé que a obra daquele historiador lhe ofereceu a ocasião para um aprofundamento 
e uma readequação de seu pensamento, o fio condutor do qual tem necessidade para conciliar as reflexões aparentemente contraditórias entre O Príncipe e os Discorsi e para lançar, desse modo, as bases de uma exigência coerente de sua meditação política. ${ }^{7}$

7 As referências bibliográficas centrais deste artigo foram: BignotTo, N. Maquiavel Republicano. São Paulo: Loyola, 1991; Colonn D'IsTria, G. L'Art Politique chez Machiavel: principes et métbode. Paris: Vrin, 1980; Larivallu, P. La Pensée Politique de Machiavel: Les Discours sur la Première Décade de Tite-Live. Nancy: Presses Universitaires de Nancy, 1982; LeforT, C. Le travail de l'oeuvre Macbiavel. Paris: Gallimard, 1972; Sasso, G. Niccolò Macbiavelli: Storia del suo pensiero politico. Bolonha: Il Mulino, 1980. 